$\xi=-1$

\title{
The Alternative Profit on Shariah-Compliant by using Compounding Theory
}

\author{
Nadhirah Gazali ${ }^{1 *}$, Nurfadhlina Abdul Halim ${ }^{1}$, Mohd Asrul Affendi Abdullah², Wan Muhamad Amir W.Ahmad ${ }^{3}$, \\ Mustafa Mamat ${ }^{4}$, Zailani Abdullah ${ }^{5}$, Kasypi Mokhtar ${ }^{6}$ \\ ${ }^{1}$ School of Informatics and Applied Mathematics, Universiti Malaysia Terengganu, 21300 Kuala Terengganu, Terengganu, Malaysia. \\ ${ }^{2}$ Department of Mathematics and Statistics, Universiti Tun Hussein Onn Malaysia, 86400 Parit Raja, Batu Pahat, Johor, Malaysia. \\ ${ }^{3}$ School of Dental Sciences, Health Campus, Universiti Sains Malaysia, 16150 Kubang Kerian, Kelantan, Malaysia. \\ ${ }^{4}$ Faculty of Informatics and Computing, Universiti Sultan Zainal Abidin, Gong Badak Campus, \\ 21300 Kuala Terengganu, Terengganu, Malaysia. \\ ${ }^{5}$ Faculty of Entrepreneurship and Business/Centre of Computing and Informatics, Universiti Malaysia Kelantan, City Campus, Locked \\ Bag 36, Pengkalan Chepa, 16100 Kota Baharu, Kelantan, Malaysia. \\ ${ }^{6}$ School of Maritime Business and Management, Universiti Malaysia Terengganu, 21300 Kuala Terengganu, Terengganu, Malaysia. \\ *Corresponding author E-mail: nadhirahgazali08@gmail.com
}

\begin{abstract}
Islamic banking and conventional banking has same aim in the financial activity which is to gain profit. Profit of Islamic finance/banking in Malaysia is based on the profit rate, while for conventional banking based on interest rate. However, both profit rate and interest rate are determined based on the same reference rate, namely base rate (BR). The determination of the components contained in the BR such as benchmark cost of funds and the statutory reserve requirement (SRR) found that there is non-compliance with the Shariah perspective because this components directly proportional to the overnight policy rate (OPR). Therefore, an alternative formula for the profit rate was built which is known as the base profit rate (BPR). Form BPR model, determination of the profit based on compounding theory. Thus, construction of BPR formula is based on the principles that are much more Shariah compliant.
\end{abstract}

Keywords: Profit Rate; Reference Rate; Base Profit rate; Shariah; Compounding Theory.

\section{Introduction}

In Malaysia, Islamic financial system is establishment since the existence of Tabung Haji Board in 19691. Afterwards, Islamic banking eventually gained foothold with the establishment of Bank Islam Malaysia Berhad (BIMB) in 19831. Thus, the Islamic banking facilities have expended to meet and serve the customers' insatiable demands for user-friendly by the establishment of various banks offering Islamic products until now ${ }^{2}$.

Islamic banking and finance same as conventional system also aims to gain profit and minimize losses. However, Islamic banking and finance must follow Islamic concept that is compliance toward Shariah, while conventional banking and finance do not have any concept in financing. Hence, there are two parts that included in the establishment of the Islamic banking that is profit and religion ${ }^{1}$. It main source is based on al-Quran, hadith, ijma and qiyas. It is to make sure there are no prohibited element in the Islamic banking such as riba (usury) ${ }^{3,4}$. In Islamic banks, all the financial activities need to gain Allah blessings and maintaining the relationship between the ummah. Besides that, profit refers to the surplus money of the principal taken by the bank from the sale and purchase transactions. The surplus is not considered as a riba if the contract agreed by both parties in the buying and selling activities. Besides that, in Islamic's law, buying and selling activity in installments is justified ${ }^{2}$.

Nevertheless, there is no significant difference the method used in determination of the profit either in Islamic banking or conven- tional banking. This is because both banks use the same reference rate in determining the profit rate which is base rate $(\mathrm{BR})^{5}$. There are problem in the construction of the BR based on Shariah concept $^{8}$. The components used in BR are has element of riba. Hence, generally profitability in Islamic products also has the element of riba ${ }^{4}$. Thus, the aim of this study was to construct an alternative formula for Sharia-compliant profit rate based on the opinion of the scholars and the size of the economy bubble by using GJLS model to describe current economic conditions.

\section{Existing Reference Rate}

In Malaysia, base rate (BR) (notation, $w$ ) formula is used in Islamic banking to determined the profit rate is given by equation $(1)^{5}$.

$w=F_{c}+\alpha$

where $F_{c}$ and $\alpha$ is benchmark cost of fund and Statutory Reserve Requirement (SRR), respectively. From (1), the profit rate of Islamic banking is given as in equation $(2)^{5}$.

$r=w+\lambda$ 
where $\lambda$ is the sum of components, which are operating cost, liquidity risk, credit risk and profit margin. These components are determined by bank.

From equation (1), BR components are determined by Bank Negara Malaysia (BNM). Thus, benchmark the cost of funds and the SRR are directly proportional to the overnight policy rate (OPR). OPR is defined as interest rate between banks ${ }^{6}$. That means, the costs of the transaction between the bank use OPR as interest rate, whether the conventional bank or Islamic banks. For example, money loan transactions will occur between banks because every bank has to make sure there is sufficient saving in the bank every day. Hence, the bank needs to repay the borrowed money with surplus which is based on OPR. As we can see here, the transactions that occur between the banks are based on money as a commodity, not real assets. When the money is used as commodities in a transaction, it is under the definition of riba ${ }^{7}$. Thus, because of BR values depend on OPR, so the profit rate of Islamic banking also has the elements of riba.

\section{Alternative Profit Rate}

Alternative profit rates proposed in this study is known as a base profit rate (BPR). The construction this formula is based on installment contract. Besides, construction of BPR based on Islamic school of jurist to determine profit margin and bubbles size as a proxy to determine the opportunity cost. Thus, this formula is transparent in terms of principal and profits. BPR formula is given as in equation (3).

$u_{T}=33.33 \%+g T$

where $u_{T}, 33.33 \%$ refer to Nadhirah Gazali et. $\mathrm{al}^{10}, g$ and $T$ is base profit rate (BPR) in $T$ year, profit margin, bubble size rate per year and number of years, respectively.

Based on the equation (3), $g$ is used in BPR formula to reflect current financial economic condition. Bubble size can be calculated by using Generalized Johansen-Ledoit-Sornette (GJLS) model is given by equation (4). The formations of this model can be referring to Nadhirah Gazali et. al ${ }^{10}$

$$
p_{1}+\exp F_{L P P L(t)}, \gamma=1
$$

By using the compounding theory, considering an installment payment on a monthly basis $(n=T \times m)$ and nominal rate $\left(i=\frac{u_{T}}{n}\right)$, where $m$ is number of times per year $1 \leq m \leq 12$. The monthly periodic payments is calculated and given by equation (5).

$$
\begin{aligned}
& S=S(1+i)^{n}-P i(1+i)^{n} \\
& S=\frac{P i(1+i)^{n}}{(1+i)^{n}-1}
\end{aligned}
$$

where $P$ is principal.

Total amount (notation, $V$ ) will be paid by customer is given as in equation (6).

$$
V=S \times n
$$

Hence, from equation (6), the profit (notation, $b$ ) is given by (7).

$$
b=V-P
$$

\section{Result}

In this study, Kuala Lumpur Composite Index (KLCI) during the year 1997 and 2008 was applied to the final model equation (4) to estimate the fundamental value and size of the bubble. The KLCI data were used in this study as Malaysia's stock market developments had a significant impact on the country. It serves as a major reference for economic performance.

First, we need to predict the bubble size by using GJLS model. We estimate the $\omega$ value by three consecutive price peaks. The best result is chosen based on MSE value. The results of the bubbles size as shown in Table 1 .

Table 1: Predicted bubbles size of KLCI 1997 and 2008.

\begin{tabular}{llll}
\hline $\begin{array}{l}\text { Time } \\
\text { interval }\end{array}$ & $\omega$ & MSE & Bubble size \\
\hline $\begin{array}{l}29 / 01 / 1993- \\
28 / 02 / 1997\end{array}$ & 65.93 & 0.2978 & 716.01 \\
$\begin{array}{l}28 / 08 / 1998- \\
31 / 01 / 2008\end{array}$ & 73.79 & 0.06182 & 845.38 \\
\hline
\end{tabular}

Bubbles size rate for 11 years is $18.07 \%$ shown in Table 1 . While, Table 2 give the result for BPR model by using compounding theory. The empirical tests on alternative profit rate are performed by considering the principal of RM300000.00 and the contract period is 9 years (108 months).

The bubbles size rate per year will be:

$$
\begin{aligned}
g & =\frac{18.07 \%}{11} \\
& =1.64 \%
\end{aligned}
$$

By using equations (8), the base profit rate (BPR) is given by the following equation:

$$
\begin{aligned}
u_{T} & =33.33 \%+1.64 \%(9) \\
& =48.09 \%
\end{aligned}
$$

From the equation (9), the periodical profit rate is $i=0.0045$. The periodic payment that will be paid by customer is given by the following:

$$
\begin{aligned}
S & =\frac{300000(0.0045)(1+0.0045)^{108}}{(1+0.0045)^{108}-1} \\
& =3505.09
\end{aligned}
$$

From equation (10), the selling price will be:

$$
\begin{gathered}
V=3505.09 \times 108 \\
=378549.72
\end{gathered}
$$

From the equation (11), the profit gained by the bank is given by the following equation:

$$
\begin{aligned}
b & =378549.72-30000000 \\
& =78549.72
\end{aligned}
$$

\section{Conclusion}

Existing profit evaluation in Malaysia is determined based on BR. However determination of BR is in line with OPR that noncompliant toward Shariah perspective. So BPR model was built to meet the requirements of Shariah perspective. This is because the profit margin is determined based on scholar opinion is to prevent any of contradiction opinion. This is to make sure there are no problems in ummah because of the difference judgment. This is because, in Islamic banking, the Shariah regulation should be clear in all activity to make sure bring prosperity in ummah. 
Besides that, because of the BPR model was built for installment payment. So, the bubble size is used as proxy to determine the opportunity cost. Bubble size is in line with the economy that makes it relevant as a proxy. This is to avoid losses to traders because if financing is done by lump sum payment the traders can generate more money.

From the empirical test on alternative profit rate model, it is proved that the establishment of base profit rate (BPR) can be applied in the real world. As a result of Table 1 shows that, financial bubbles usually occur every 10 years ${ }^{7}$. In Table 2 the selling price generates is RM378549.72, whereas the principal is RM300000.00. This show that, BPR model more shariahcompliant because no element of ghabn fashisy.

In conclusion, this alternative model is transparent and clear in determination of the profit rate that compliance towards Shariah. Besides, there is no element of riba that can be found out in this model.

\section{References}

[1] Sudin Haron \& Wan Nursofiza WA (2009), Islamic finance and banking system philosophies, principle \& practice, Kuala Lumpur: MC Graw Hill.

[2] Ridzwan A \& Aziz CS (2009), Pemakaian maslahah terhadap konsep nilai masa wang dalam sistem perbankan Islam di Malaysia. Journal Fiqh 6, 87-106.

[3] Hahnel R (1998), Capitalist globalism in crisis https://zcomm.org/zmagazine/capitalistglobalism-in-crisis-byrobin-hahnel-1/.

[4] Zaharuddin AR (2012), Contracts and the products of Islamic banking, 2nd edn, Malaysia: CERT Publications Sdn. Bhd.

[5] Bank Negara Malaysia. Annual report 2014 (2014), Kuala Lumpur: Bank Negara Malaysia.

[6] Zaharuddin AR (2015), Kenaikan OPR dan BLR: kesan terhadap kita. http://zaharuddin.net/senarai-lengkap-artikel/3/1035-kenaikanopr-a-blr-kesan-terhadap-kita.html

[7] Nurfadhlina Abdul Halim (2013), Pemodelan matematik instrument sewa-beli Islam alternatif berkonsepkan perkongsian untung-rugi, Tesis PhD, Universiti Kebangsaan Malaysia.

[8] Nadhirah Gazali \& Nurfadhlina Abdul Halim (2016), Comparison of reference rates determination in Malaysia, The 7th International Conference on Postgraduate Education, 227-231.

[9] M. Mohammad Taqiuddin, Joni Tamkin B, Mohd Sollehuddin S \& Ahmad Azam S (2012), Analisis kaedah pengukuran untung (AlRibh) dari perspektif Mu'amalat, Jurnal Teknologi 59, 135-140.

[10] Nadhirah Gazali, Nurfadhlina Abdul Halim \& Puspa Liza Ghazali (2017), Alternative profit rate shariah-compliant for Islamic banking, J.Phys.:Conf. Ser. 890 
Table.2. Amortization table for BPR model in compounding theory

\begin{tabular}{|c|c|c|c|c|c|}
\hline Period & Periodical payment, $S$ & Periodical profit rate & Profit amortisation & Principal amortisation & Remaining principal \\
\hline 0 & & & & & 300000 \\
\hline 1 & 3505.09 & 0.0045 & 1335.83 & 2169.25 & 297830.75 \\
\hline 2 & 3505.09 & 0.0045 & 1326.17 & 2178.91 & 295651.84 \\
\hline 3 & 3505.09 & 0.0045 & 1316.47 & 2188.61 & 293463.22 \\
\hline 4 & 3505.09 & 0.0045 & 1306.73 & 2198.36 & 291264.87 \\
\hline 5 & 3505.09 & 0.0045 & 1296.94 & 2208.15 & 289056.72 \\
\hline$\vdots$ & $\vdots$ & $\vdots$ & $\vdots$ & $\vdots$ & $\vdots$ \\
\hline 105 & 3505.09 & 0.0045 & 61.74 & 3443.34 & 10422.30 \\
\hline 106 & 3505.09 & 0.0045 & 46.41 & 3458.68 & 6963.62 \\
\hline 107 & 3505.09 & 0.0045 & 31.01 & 3474.08 & 3489.55 \\
\hline 108 & 3505.09 & 0.0045 & 15.54 & 3489.55 & 0.00 \\
\hline
\end{tabular}

